\title{
Screening and analysis of water quality of Zea River in Kurdistan region, Iraq
}

\author{
Najmaldin E. Hassan*, Sagvan A. M. Ali \\ Department of Environmental Science, Faculty of Science, Zakho University, Zakho, Iraq
}

\section{A R T I C LE I N F O}

\section{Article history:}

Received 15 May 2016

Received in revised form

20 August 2016

Accepted 22 August 2016

\section{Keywords:}

Water quality

Laboratory testing

water measurement

\begin{abstract}
A B S T R A C T
The present investigation deals with the physico-chemical analysis of Zea River which passes through the Deralok City, an agricultural town of Duhok province. The objective of the study was to provide baseline information on its physical and chemical characteristics as well as evaluate its water quality. Water samples were collected during dry and wet seasons from seven stations and analyzed for various physico-chemical parameters. Assessment of temperature, $\mathrm{pH}$, Dissolved Oxygen, total alkalinity, turbidity, chloride, hardness, dissolved oxygen, calcium, Sulphate, total dissolved solids (TDS), Biochemical Oxygen Demand (BOD), Chemical Oxygen Demand (COD) and Electrical Conductivity were carried out monthly during November, 2014 to June, 2015. Results showed significant alterations in the physicochemical parameters. The analyzed data of water body was interpreted in relation to pollution status and biodiversity indices for assessment of aquatic fauna. Atmospheric temperature ranged from 2.12 to 45.25 (o). Water temperature ranged from 10.71 to $16.01\left({ }^{\circ} \mathrm{C}\right)$. $\mathrm{pH}$ ranged from 7.27 to 8.73 , dissolved oxygen from 7.53 to 9.01 (mg/l), electrical conductivity from 316 to $398(\mu \mathrm{S} / \mathrm{cm})$, total dissolved solids from 202 to $255(\mathrm{mg} / \mathrm{l})$, turbidity from 86 to 92 (NTU), total hardness from 206 to $216(\mathrm{mg} / \mathrm{l})$, total alkalinity from 58 to 76 (mg/l) and total acidity (53-83 mg l-1), BOD (2.7-3.7 mg l-1), COD (1.7-2.1 mg l-1). Results show that there is no serious problem regarding the parameters checked in this study. So, the water can be used as drinking water for Deralok city and another city without any serious problem. The results suggest that refuse disposal, fertilizer use, and natural phenomena e.g. soil erosion; flooding, etc. may have contributed in various ways to the impairment of the water quality of the studied sites. Although the results do not indicate adverse pollution status of any of the sites, they provided the need for further investigations and monitoring. The water from the river which is called Zea, travels from turkey to Kurdistan in a small city called Deralok it also goes through the middle of the city. This separates the city into 2 pieces. From Deralok the river goes through many villages and woods then it joins with another river called the blue (shin) river. Also the Zae River is $75 \mathrm{~km}$ far away from the province of Duhok.
\end{abstract}

(C) 2016 The Authors. Published by IASE. This is an open access article under the CC BY-NC-ND license (http://creativecommons.org/licenses/by-nc-nd/4.0/).

\section{Introduction}

Most ancient civilizations grew along the banks of rivers. Even today, millions of people all over the world live on the banks of rivers and depend on them for their survival.

Water is an elixir of life. It governs the evolution and function of the universe on the earth hence water 'mother of all living world'. Majority of water available on the earth is saline in nature; only small

\footnotetext{
* Corresponding Author.

Email Address: najmaldin.hassan@uoz.edu.krd (N. Hassan) http://dx.doi.org/10.21833/ijaas.2016.08.011

2313-626X/C) 2016 The Authors. Published by IASE.

This is an open access article under the CC BY-NC-ND license

(http://creativecommons.org/licenses/by-nc-nd/4.0/)
}

quantity is fresh water. Freshwater has become a scare commodity due to over exploitation and pollution (Gupta and Shukle, 2006; Patil and Tijare, 2001; Singh and Mathur, 2005).

Water pollution by effluent has become a question of considerable public and scientific concern in the light of evidence of their extreme toxicity to human health and to biological ecosystems (Anazawa et al., 2004). The occurrence of heavy of metals in industrial and municipal sewage effluents constitute a major source of the heavy metals entering aquatic media. Hence there should be regular assessment of these sewage effluents to ensure that adequate measures are taken to reduce pollution level to the minimum. 
Seasonal variations in precipitation, surface runoff, ground water flow, interception and abstraction strongly affect river discharge and, consequently the concentrations of pollutants in river water (Khadka and Khanal, 2008; Mtethiwa et al., 2008; Vega et al., 1998).

Rivers in watersheds with substantial agricultural and urban land use experience increased inputs and varying compositions of organic matter (Sickman et al., 2007) and excessive concentrations of phosphorus and other nutrients from fertilizer application and watershed releases (Easton et al., 2007).

The geography and the topography of an area also affect the water quality of that area. Anthropogenic activities, natural processes e.g. erosion, weathering, geochemical and geological characteristics of the environment as well as the ever increasing population of the world have kept changes in natural water bodies constant (Arain et al., 2008; Adefemi and Awokunmi, 2010; Nduka, 2008; Bellingham, 2012). As a result, physical, chemical and biological parameters that influence water quality keep changing. Therefore, regular quality monitoring of water bodies to ascertain these changes from time to time is necessary (Arain et al., 2008). The reasons for this are enormous. Water is an essential component for survival of life on earth, and the minerals it contains are important for humans as well as for earth and aquatic life (Arain et al., 2008; Lawson, 2011; Murhekar, 2011). Monitoring of water quality will ensure protection of public health, since about $90 \%$ of water supply globally comes from large water bodies.

The interactions of both the physical and chemical properties of water play a significant role in composition, distribution, abundance, movements and diversity of aquatic organisms (Mustapha and Omotosho, 2005; Sangpal et al., 2011; Murangan and Prabaharan, 2012; Deepak and Singh, 2014).

In particular, fish populations are highly dependent upon the variations of physicochemical characteristics of their aquatic habitat which supports their biological functions (Mushahida-AlNoor and Kamruzzaman, 2013; Blaber, 2000; Iqbal et al., 2004; Koloanda and Oladimeji, 2004; Ojutiku and Kolo, 2011).

Marshall and Elliot (1998), noted significant correlations between a number of individual fish species and water temperature, salinity, dissolved oxygen and depth. Blaber and Blaber (1980) reported that turbidity is associated with productive feeding areas and provides cover for fishes. Other studies have determined that fish move away from alkaline waters when pH levels approach 9.06-10.0, unless more important survival factors outweigh avoidance, including food availability or lower predation levels (Serafy and Harrel, 1993; Scott et al., 2005). These factors are responsible for distribution of organisms in different fresh water habitats according to their adaptations, which allow them to survive in a specific habitat.
Measurement of physical attributes serves as indicators of some forms of pollution, changes in temperature may, indicate the presence of certain effluents while changes in stream width, depth, and velocity, turbidity and rock size may indicate dredging in the area.

Chemical characteristics of a healthy water body affect its toxicity and also aesthetic qualities, such as how water looks, smells and tastes. Assessment of water quality by its chemistry includes measures of many elements and molecules dissolved or suspended in the water and can be used to detect imbalances within the ecosystem. Such imbalances may indicate the presence of certain pollutants as suggested, by Dzeroski et al. (2002). The commonly measure chemical parameters includes $\mathrm{pH}$, alkalinity, hardness, nitrates, nitrites and ammonia, total phosphate and dissolved oxygen for Biochemical Oxygen Demand (BOD). Measurements such as conductivity and density in chemical measurement actually indicate the physical presence of pollutants in water.

The $\mathrm{pH}$ of water determines the solubility and bioavailability of chemical constituents such as nutrients and heavy metals. Metals tend to be more toxic at lower $\mathrm{pH}$ because they are more soluble. Though an increase in $\mathrm{pH}$ levels may have no direct impact on aquatic life, they greatly influence the availability and solubility of all chemical forms in the water and this might aggravate nutrient problems leading to a destabilization of the ecosystem.

In the urban environment, sewage discharges are a major component of water pollution, It contributes to oxygen demand and nutrient loading thereby promoting growth of toxic algae and other aquatic plants, This results in the destabilization of the aquatic ecosystem (Olajire and Impekperia, 2000; Morrison et al., 2001).

\section{Materials and methods}

\subsection{Site selection}

Location: Deralok, Amedye, Duhok ProvinceKurdistan Region/Iraq. Latitude: $35^{\circ} 59^{\prime} 26^{\prime \prime} \mathrm{N}$. Longitude: $43^{\circ} 20^{\prime} 39^{\prime \prime}$ E. The Great Zab or Upper Zab (Arabic: al-Zāb al-Kabīr), Kurdish: Zêy Badînan or Zêyê Mezin, is an approximately 400-kilometre (250 mi) long river flowing through Turkey and Iraq. It rises in Turkey near Lake Van and joins the Tigris in Iraq south of Mosul. The drainage basin of the Great Zab covers approximately 40,300 square kilometers $(15,600 \mathrm{sq} \mathrm{mi})$, and during its course, the rivers collects the water from many tributaries. The river and its tributaries are primarily fed by rainfall and snowmelt- as a result of which discharge fluctuates highly throughout the year.

Along the area of the river segment are shopping complexes, a hospital, banks, a car park and a mini market for the sale of fresh vegetables and fish (Fig. 1). 


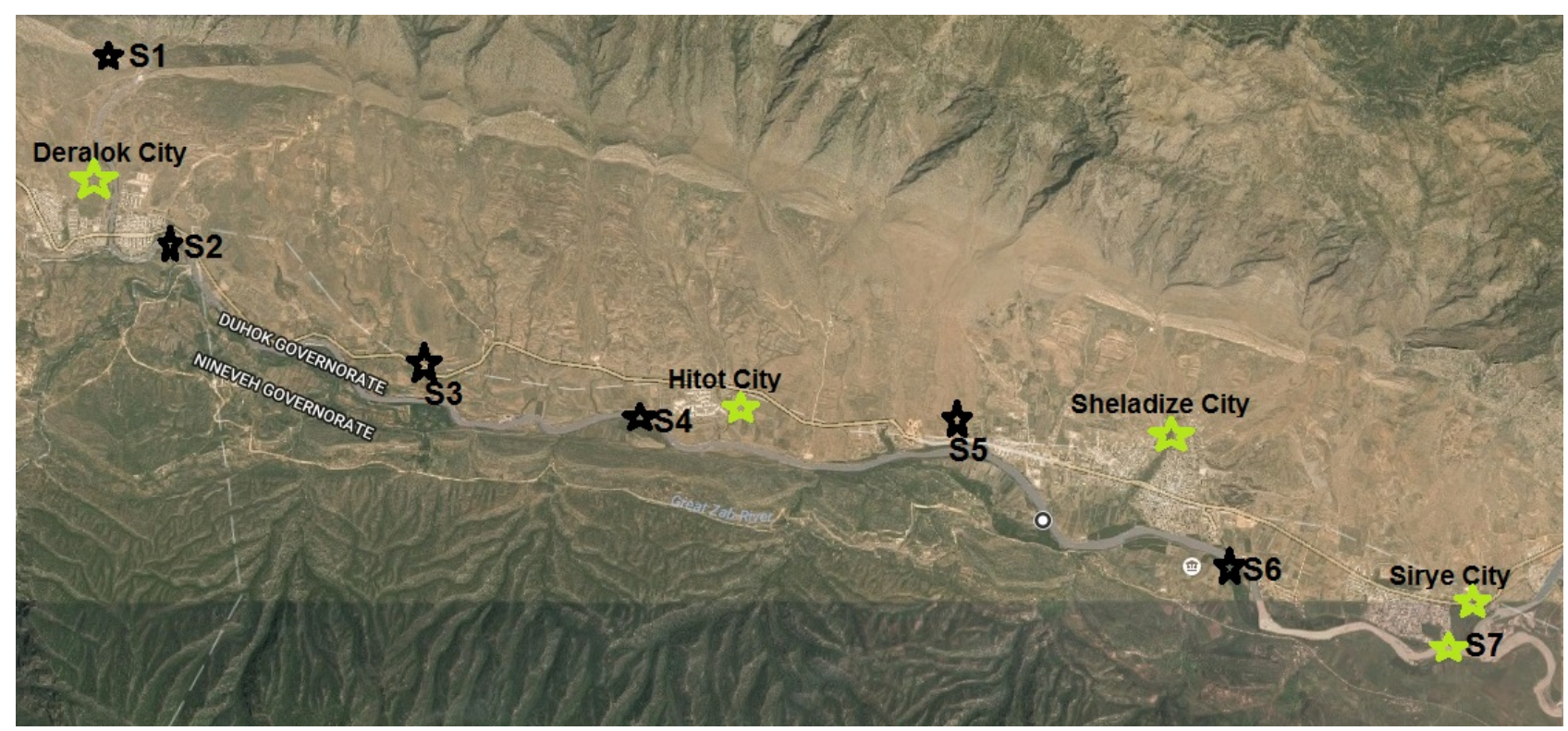

Fig. 1: Site location

\subsection{Sample collection}

Monthly variations of physicochemical characteristics of water were studied from November 2014 to June, 2015. The surface water samples from Zea River were collected from seven sampling stations during 8.30 am to $17.30 \mathrm{pm}$. Samples were collected at monthly interval in plastic cans of two liters capacity. Water temperature, Air temperature, $\mathrm{pH}$ and Humidity recorded at sampling station. Collected water samples were brought immediately to the laboratory for the estimation of various physicochemical parameters like, Conductivity, Total solid, Dissolved oxygen, Total Alkalinity, Total hardness, Caco3, $\mathrm{Ca}++, \mathrm{Mg}++$. Physicochemical parameters were analyzed as per standard methods (Trivedy and Goel, 1984).
The water samples were collected in clean plastic containers. Before sampling, the bottles were rinsed three times with sample water before being filled with the sample. And labeled in the field the temperatures of the samples were measured in the field itself at the time of sample Collection.

Initially, the pre washed bottles were rinsed with sample water. The closed bottle was dipped in the lake at the depth of $0.5 \mathrm{~m}$, and then a bottle was opened inside and was closed again to bring it out at the surface.

\section{Results}

A total of 14 water samples were collected over a period of eight months. 8 samples from each sampling point. The results obtained are as presented in the Table 1 (Fig. 2 and Fig. 3).

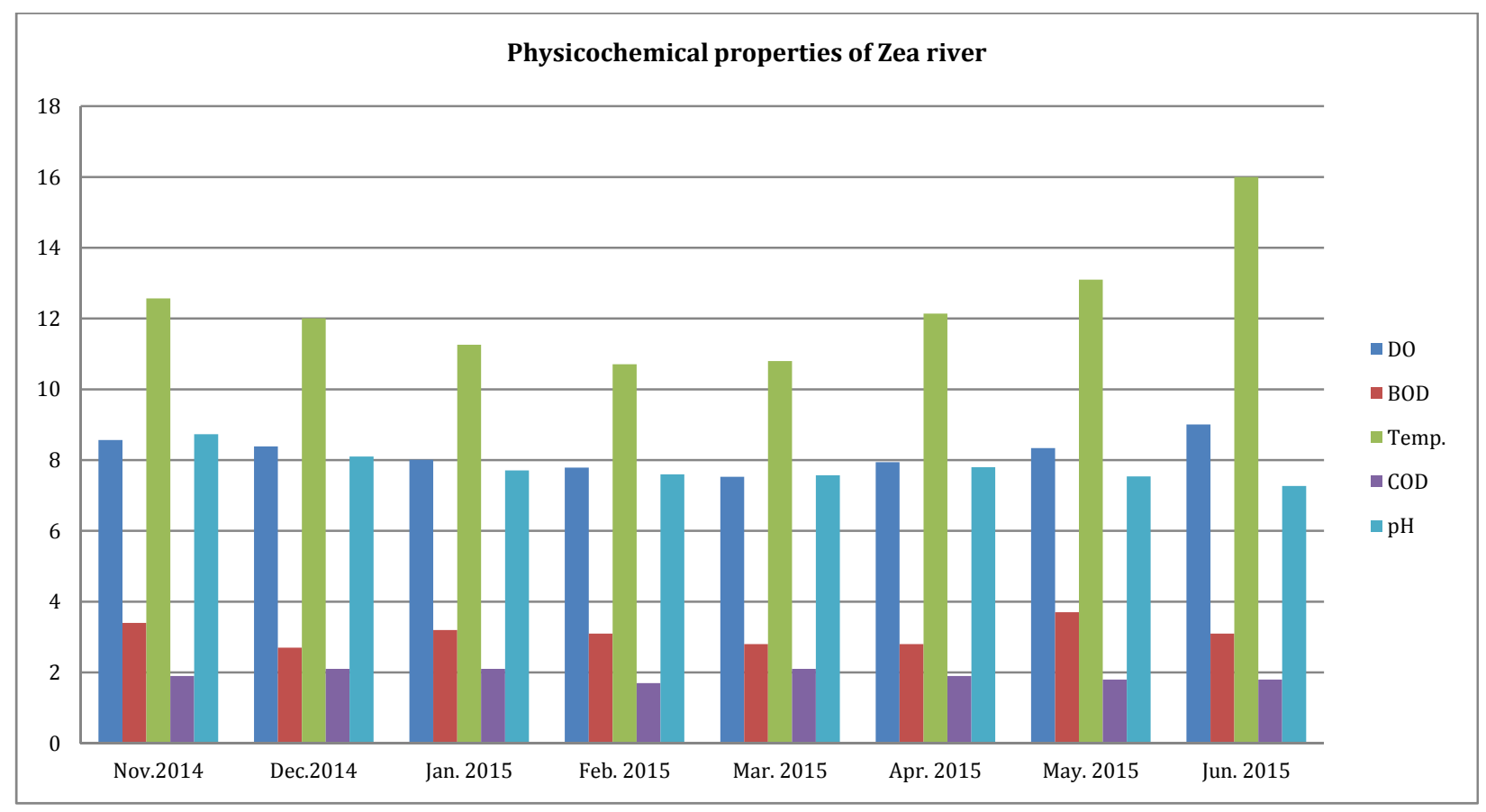

Fig. 2: Physics properties of Zea River 
Table 1: Physicochemical properties of the Zea River

\begin{tabular}{|c|c|c|c|c|c|c|c|c|c|}
\hline \multicolumn{2}{|c|}{ Physio- chemical parameters } & $\begin{array}{l}\text { Nov } \\
2014\end{array}$ & $\begin{array}{c}\text { Dec } \\
2014\end{array}$ & $\underset{2015}{\operatorname{Jan}}$ & $\begin{array}{c}\text { Feb } \\
2015\end{array}$ & $\begin{array}{c}\text { Mar } \\
2015\end{array}$ & $\begin{array}{c}\text { Apr } \\
2015\end{array}$ & $\begin{array}{c}\text { May } \\
2015\end{array}$ & $\underset{2015}{\operatorname{Jun}}$ \\
\hline & $\min$ & 7.7 & 7.9 & 7.8 & 7.6 & 7.3 & 7.8 & 7.9 & 8.4 \\
\hline \multirow[t]{3}{*}{ do (mg/l) } & $\max$ & 8.99 & 8.99 & 8.2 & 8.1 & 7.7 & 8.1 & 8.7 & 9.5 \\
\hline & mean & 8.57 & 8.39 & 8.01 & 7.79 & 7.53 & 7.94 & 8.34 & 9.01 \\
\hline & $\min$ & 1.6 & 1.4 & 2.3 & 2.1 & 2.0 & 1.9 & 2.3 & 2.2 \\
\hline \multirow[t]{3}{*}{ bod(mg/l) } & $\max$ & 4.8 & 3.9 & 5.1 & 4.4 & 4.2 & 3.9 & 4.5 & 3.9 \\
\hline & mean & 3.4 & 2.7 & 3.2 & 3.1 & 2.8 & 2.8 & 3.7 & 3.1 \\
\hline & $\min$ & 11.3 & 10.1 & 9.6 & 7.2 & 9.5 & 11.7 & 12.7 & 14.5 \\
\hline \multirow[t]{2}{*}{ water temperature } & $\max$ & 15.4 & 14.2 & 12.3 & 11.8 & 11.3 & 12.9 & 13.6 & 17.3 \\
\hline & mean & 12.57 & 12.01 & 11.26 & 10.71 & 10.8 & 12.14 & 13.1 & 16.01 \\
\hline \multirow{4}{*}{$\mathrm{ca}$} & $\min$ & 152 & 160 & 152 & 142 & 148 & 140 & 150 & 154 \\
\hline & $\max$ & 162 & 170 & 162 & 160 & 156 & 152 & 164 & 162 \\
\hline & mean & 156 & 164 & 156 & 148 & 152 & 144 & 154 & 158 \\
\hline & $\min$ & 52 & 48 & 52 & 58 & 58 & 60 & 56 & 52 \\
\hline \multirow[t]{2}{*}{$\mathrm{mg}$} & $\max$ & 64 & 56 & 62 & 64 & 62 & 66 & 64 & 64 \\
\hline & mean & 58 & 52 & 58 & 60 & 60 & 62 & 60 & 58 \\
\hline \multirow{3}{*}{$\begin{array}{l}\text { conductivity } \\
\left(\mu \mathrm{scm}^{-}\right)\end{array}$} & $\min$ & 342 & 360 & 339 & 326 & 310 & 342 & 347 & 384 \\
\hline & $\max$ & 351 & 381 & 351 & 341 & 321 & 358 & 396 & 418 \\
\hline & mean & 346 & 368 & 345 & 333 & 316 & 351 & 374 & 398 \\
\hline \multirow{3}{*}{$\begin{array}{l}\text { alkalinity (mg/l } \\
\text { na }_{2} \mathrm{Co}_{3}\end{array}$} & $\min$ & 68 & 62 & 54 & 56 & 48 & 49 & 52 & 50 \\
\hline & $\max$ & 98 & 84 & 77 & 81 & 76 & 73 & 75 & 79 \\
\hline & mean & 76 & 72 & 61 & 63 & 59 & 58 & 61 & 68 \\
\hline \multirow{4}{*}{$\begin{array}{l}\text { acidity (mg/l } \\
\mathrm{h}_{2} \mathrm{SO}_{4}\end{array}$} & $\min$ & 72 & 70 & 65 & 54 & 50 & 62 & 69 & 75 \\
\hline & $\max$ & 78 & 77 & 75 & 66 & 57 & 80 & 85 & 89 \\
\hline & mean & 74 & 73 & 71 & 59 & 53 & 71 & 76 & 83 \\
\hline & $\min$ & 8.71 & 7.8 & 7.4 & 7.1 & 7.2 & 7.1 & 7.0 & 6.8 \\
\hline \multirow[t]{3}{*}{ ph } & $\max$ & 8.82 & 8.4 & 8.1 & 8.2 & 8.1 & 8.3 & 8.1 & 8.0 \\
\hline & mean & 8.73 & 8.1 & 7.71 & 7.6 & 7.57 & 7.8 & 7.54 & 7.27 \\
\hline & $\min$ & 30 & 32 & 33 & 31 & 32 & 30 & 31 & 31 \\
\hline \multirow[t]{3}{*}{ sulphate ion(mg/l) } & $\max$ & 37 & 36 & 38 & 38 & 38 & 37 & 38 & 38 \\
\hline & mean & 34 & 34 & 35 & 34 & 35 & 33 & 34 & 34 \\
\hline & $\min$ & 1.1 & 1.5 & 1.7 & 1.2 & 1.8 & 1.5 & 1.3 & 1.2 \\
\hline \multirow[t]{3}{*}{$\operatorname{cod}(\mathrm{mg} / \mathrm{l})$} & $\max$ & 2.6 & 2.7 & 2.5 & 1.9 & 2.3 & 2.1 & 2.2 & 2.3 \\
\hline & mean & 1.9 & 2.1 & 2.1 & 1.7 & 2.1 & 1.9 & 1.8 & 1.8 \\
\hline & $\min$ & 82 & 80 & 84 & 82 & 84 & 86 & 84 & 82 \\
\hline \multirow[t]{2}{*}{ turbidity (ntu) } & $\max$ & 96 & 96 & 98 & 94 & 94 & 96 & 96 & 94 \\
\hline & mean & 88 & 86 & 92 & 86 & 88 & 90 & 88 & 90 \\
\hline \multirow{4}{*}{$\begin{array}{l}\text { total hardness } \\
\text { caco3 }(\mathrm{mg} / \mathrm{l})\end{array}$} & $\min$ & 192 & 196 & 202 & 200 & 204 & 198 & 202 & 206 \\
\hline & $\max$ & 222 & 224 & 228 & 220 & 224 & 216 & 222 & 228 \\
\hline & mean & 214 & 216 & 214 & 208 & 212 & 206 & 214 & 216 \\
\hline & $\min$ & 219 & 230 & 217 & 209 & 198 & 219 & 222 & 246 \\
\hline \multirow[t]{2}{*}{ tds (mg/l) } & $\max$ & 225 & 244 & 227 & 218 & 205 & 229 & 253 & 268 \\
\hline & mean & 221 & 236 & 221 & 213 & 202 & 225 & 239 & 255 \\
\hline
\end{tabular}

Physicochemical properties of Zea river

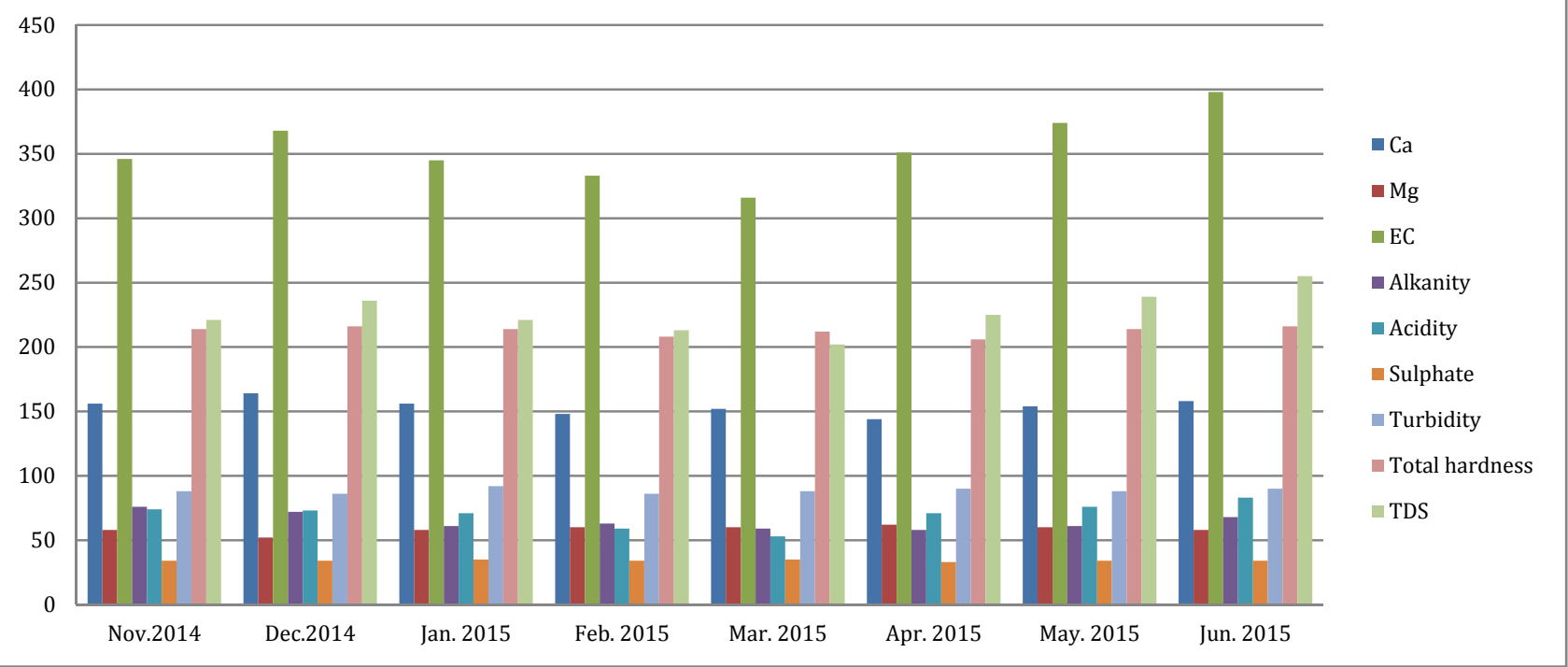

Fig. 3: Chemical properties of Zea River 


\section{Discussion and conclusion}

It appears to me through this study that there is a little variation in the values of most water measurements that we have taken from the Zea River as shown in the above table from the period time of yeas 2014-2015. This is due several factors including physical and other humanitarian activities; the physical factors such as difference in seasons, temperature, short or length of the day, flooding, geological region that experienced by the Zea River. Human activity, there are various human activities on the bank of the river that have also a little impact in the surface water quality but these factors fortunately did not affect the water quality of the Zea river. The results of statistical samples that have been tested from the surface water of the Zea river from the period time November 2014 to June 2015 as shown in Table 2 was not exceed allowable measurements internationally in the period time that included study.

\section{Recommendation}

We recommend the government agencies and organizations of environmentalist not allow the construction of laboratories or industrial productivity or hospital on both banks of the Zea river but only after implementation of all the conditions relating to gaseous emissions and discharging of waste which are considered hazard to health and environment system.

Table 2: Summary of basic statistics for Zea River

\begin{tabular}{|c|c|c|c|c|c|}
\hline $\begin{array}{l}\text { physio-chemical } \\
\text { parameters }\end{array}$ & Range & Mean & $\begin{array}{l}\text { Standard } \\
\text { Deviation }\end{array}$ & $\begin{array}{c}\text { Threshold }= \\
X+2 s\end{array}$ & $\begin{array}{c}\text { Coefficient of } \\
\text { Variation }\end{array}$ \\
\hline do (mg/l) & $7.53-9.01$ & 8.2 & 0.397 & 8.994 & 0.048 \\
\hline $\operatorname{bod}(\mathrm{mg} / \mathrm{l})$ & $2.7-3.7$ & 3.1 & 0.273 & 3.646 & 0.088 \\
\hline water temperature & 10.71- 16.01 & 12.33 & 1.52 & 15.37 & 0.123 \\
\hline $\mathrm{ca}$ & $144-164$ & 154 & 5.35 & 164.7 & 0.035 \\
\hline mg & $52-62$ & 58.5 & 2.79 & 64.08 & 0.048 \\
\hline $\begin{array}{l}\text { conductivity } \\
\left(\mu \mathrm{scm}^{-}\right)\end{array}$ & $316-398$ & 354 & 21.97 & 397.94 & 0.062 \\
\hline alkalinity $\left(\mathrm{mg} / \mathrm{l} \mathrm{na}{ }_{2} \mathrm{CO}_{3}\right.$ & $58-76$ & 64.75 & 4.96 & 74.67 & 0.077 \\
\hline $\begin{array}{c}\text { acidity }(\mathrm{mg} / \mathrm{l} \\
\mathrm{h}_{2} \mathrm{SO}_{4}\end{array}$ & $53-83$ & 70 & 8.1 & 86.2 & 0.12 \\
\hline ph & $7.27-8.73$ & 7.79 & 0.41 & 8.61 & 0.052 \\
\hline sulphate ion(mg/l) & $33-35$ & 34.13 & 0.54 & 35.21 & 0.016 \\
\hline $\operatorname{cod}(\mathrm{mg} / \mathrm{l})$ & $1.7-2.1$ & 1.93 & 0.108 & 2.146 & \\
\hline turbidity (ntu) & $86-92$ & 88.5 & 1.63 & 91.76 & 0.018 \\
\hline $\begin{array}{l}\text { total hardness caco3 } \\
(\mathrm{mg} / \mathrm{l})\end{array}$ & $206-216$ & 212.5 & 2.79 & 218.08 & 0.013 \\
\hline $\mathrm{tds}(\mathrm{mg} / \mathrm{l})$ & $202-255$ & 227 & 14.188 & 255.376 & 0.063 \\
\hline
\end{tabular}

Monitoring and control irrigation of agricultural fields located on both banks of Zea River by team of specialists of agriculture, health and environment to oversee how to use the different chemical fertilizer and how to mix the required quantity of pesticides and herbal in the spray operations in the agricultural field, in order to avoid the affect impact of pollution on the surface water quality and to maintain the health and ecological system.

\section{References}

Adefemi SO and Awokunmi EE (2010). Determination of physico-chemical parameters and heavy metals in water samples from Itaogbolu area of Ondo-State, Nigeria. African Journal of Environmental Science and Technology, 4(3): 145-148.

Anazawa K, Kaida Y, Shinomura Y, Tomiyasu T and Sakamoto H (2004). Heavy-metal distribution in river waters and sediments around a" firefly village", Shikoku, Japan: Application of multivariate analysis. Analytical Sciences, 20(1): 79-84.
Arain MB, Kazi TG, Jamali MK, Afridi HI, Baig JA, Jalbani N and Shah AQ (2008). Evaluation of physico-chemical parameters of Manchar Lake water and their comparison with other global published values. Pakistan Journal of Analytical and Environmental Chemistry, 9(2): 101-109.

Bellingham K (2009). Physicochemical parameters of natural waters. Stevens Water Monitoring Systems, Inc. (accessed on 20/07/2012 from http://www.stevenswater.com)

Blaber SJ (2008). Tropical estuarine fishes: ecology, exploration and conservation. John Wiley \& Sons, New Jersey, USA.

Blaber SJM and Blaber TG (1980). Factors affecting the distribution of juvenile estuarine and inshore fish. Journal of Fish Biology, 17(2): 143-162.

Deepak S and Singh NU (2014). The Relationship between Physico-chemical Characteristics and Fish Production of Mod sagar Reservoir of Jhabua District, MP, India. Research Journal of Recent Sciences, 3: 82-86. 
Džeroski S, Demšar D and Grbović J (2000). Predicting chemical parameters of river water quality from bioindicator data. Applied Intelligence, 13(1): 7-17.

Easton ZM, Gérard-Marchant P, Walter MT, Petrovic AM and Steenhuis TS (2007). Identifying dissolved phosphorus source areas and predicting transport from an urban watershed using distributed hydrologic modeling. Water Resources Research, 43(11): W11414. doi:10.1029/2006WR005697.

Gupta GK and Shukla R (2006). Physiochemical and bacteriological quality in various sources of drinking water from Auriya District (UP) industrial area. Pollution Research, 23(4): 205209.

Iqbal F, Ali M, Salam A, Khan BA, Ahmad S, Qamar M and Umer K (2004). Seasonal variations of physico-chemical characteristics of River Soan water at Dhoak Pathan Bridge (Chakwal), Pakistan. International Journal of Agriculture and Biology, 6(1): 89-92.

Khadka RB and Khanal AB (2008). Environmental management plan (EMP) for Melamchi water supply project, Nepal. Environmental Monitoring and Assessment, 146(1-3): 225-234.

Koloanda RJ and Oladimeji AA (2004). Water quality and some nutrient levels in Shiroro Lake, Niger State, Nigeria. Journal of Aquatic Sciences, 19(2): 99-106.

Lawson EO (2011). Physico-chemical parameters and heavy metal contents of water from the Mangrove Swamps of Lagos Lagoon, Lagos, Nigeria. Advances in Biological Research, 5(1): 08-21.

Marshall S and Elliott M (1998). Environmental influences on the fish assemblage of the Humber estuary, UK. Estuarine, Coastal and Shelf Science, 46(2): 175-184.

Morrison G, Fatoki OS, Persson L and Ekberg A (2001). Assessment of the impact of point source pollution from the Keiskammahoek Sewage Treatment Plant on the Keiskamma River-pH, electrical conductivity, oxygen-demanding substance (COD) and nutrients. Water SA, 27(4): 475-480.

Mtethiwa AH, Munyenyembe A, Jere $\mathrm{W}$ and Nyali E (2008). Efficiency of oxidation ponds in wastewater treatment. International Journal of Environmental Research, 2(2):149-152.

Murangan AS and Prabaharan C (2012). Fish diversity in relation to physico-chemical characteristics of Kamala basin of Darbhanga District, India. International Journal of Pharmaceutical and Biological Archives, 3(1): 211-217.
Murhekar GH (2011). Determination of physicochemical parameters of surface water samples in and around Akot City. International Journal of Research in Chemistry and Environment, 1(2): 183-187.

Mushahida-Al-Noor S and Kamruzzaman S (2013). Spatial and Temporal Variations in Physical and Chemical Parameters in Water of Rupsha River and Relationship with Edaphic Factors in Khulna South Western Bangladesh. International Journal of Science and Research, 2(1): 460-467.

Mustapha MK and Omotoso JS (2005). An assessment of the physico-chemical properties of Moro lake. African Journal of Applied Zoology and Environmental Biology, 7(1): 73-77.

Nduka JK, Orisakwe OE and Ezenweke LO (2008). Some physicochemical parameters of potable water supply in Warri, Niger Delta area of Nigeria. Scientific Research and Essays, 3(11): 547-551.

Ojutiku RO and Kolo RJ (2011). Temporal and spatial variations in some physico-chemical parameters of River Chanchaga, Niger State, Nigeria. Journal of Applied Biosciences, 47(11): 3242- 3255.

Olajire AA and Imeokparia FE (2000). A study of the water quality of the Osun River: Metal monitoring and geochemistry. Bulletin of the Chemical Society of Ethiopia, 14(1):1-18.

Patil DB and Tijare RV (2001). Investigation of Pollution Mystery of Suspected Carcinogen $\mathrm{Cr}$ (VI) and it's Control. Journal Of Industrial Pollution Control, 17(1): 43-47.

Sangpal RR, Kulkurni VD and Nadurkar YM (2011). An assessment of the physic-chemical properties to study the pollution potential of Ujjani Reservoir. Solapur district, India. ARPN Journal of Agricultural and Biological Science, 6(3): 34-38.

Scott DM, Lucas MC and Wilson RW (2005). The effect of high $\mathrm{pH}$ onion balance, nitrogen excretion and behaviour in freshwater fish from an eutrophic lake: a laboratory and field study. Aquatic Toxicology, 73(1): 31-43.

Serafy JE and Harrell RM (1993). Behavioural response of fishes to increasing $\mathrm{pH}$ and dissolved oxygen: field and laboratory observations. Freshwater Biology, 30(1): 53-61.

Sickman JO, Zanoli MJ and Mann HL (2007). Effects of urbanization on organic carbon loads in the Sacramento River, California. Water Resources Research, 43(11): W11422. doi:10.1029/2007WR005954.

Singh RP and Mathur P (2005). Investigation of variations in physico-chemical characteristics of a fresh water reservoir of Ajmer city, Rajasthan. Indian Journal of Environmental Sciences, 9(1): 57-61. 
Trivedy RK and Goel PK (1984). Chemical and biological methods for water pollution studies. Environmental publications, Karad, India.
Vega M, Pardo R, Barrado E and Debán L (1998). Assessment of seasonal and polluting effects on the quality of river water by exploratory data analysis. Water Research, 32(12): 3581-3592. 